\title{
DIFFERENTIATED INSTRUCTION: APA, MENGAPA DAN BAGAIMANA PENERAPANNYA
}

\author{
Eni Defitriani ${ }^{1}$ \\ Pendidikan Matematika FKIP Universitas Batanghari Jambi ${ }^{1}$ \\ Email: eni.defitriani@unbari.ac.id
}

\begin{abstract}
ABSTRAK
Setiap siswa unik. Mereka hadir dengan karakteristik yang berbeda. Guru sebagai pemimpin dalam proses pembelajaran, dituntut agar dapat merangkul perbedaan karakteristik tersebut dan mengembangkan potensi yang dimiliki oleh setiap siswa. Sehingga, tidak ada siswa yang bodoh. Hanya saja mereka belum menemukan cara belajar yang tepat untuk mengembangkan potensinya. Salah satu cara yang memastikan bahwa semua siswa belajar adalah melalui Differentiated Instruction (DI). DI adalah suatu pembelajaran yang disesuaikan dengan kebutuhan siswa dengan tujuan untuk memaksimalkan potensi setiap siswa. DI disusun berdasarkan perbedaan siswa yang meliputi kesiapan belajar, minat, dan profil belajar yang dirancang dengan membedakan isi, proses, dan produk.
\end{abstract}

Kata kunci:

Pembelajaran, Differentiated Instruction

\begin{abstract}
Every student is unique. They come with different characteristics. The teacher as a leader in the learning process, is required to be able to embrace these different characteristics and develop the potential possessed by each student. So, there are no stupid students. It's just that they have not found the right way of learning to develop their potential. One way to ensure that all students learn is through Differentiated Instruction (DI). DI is a learning that is tailored to the needs of students with the aim to maximize the potential of each student. DI is arranged based on students' differences which include learning readiness, interests, and learning profiles that are designed by differentiating content, processes, and products.
\end{abstract}

Keywords:

Learning, Differentiated Instruction

\section{PENDAHULUAN}

Setiap siswa unik. Layaknya sidik jari, mereka mempunyai ciri khas tersendiri. Mereka hadir dengan karakteristik yang berbeda: baik itu sebagai bawaan sejak lahir maupun pengaruh lingkungan. Karakteristik tersebut meliputi perkembangan kognitif, bakat, minat, sikap, motivasi belajar, gaya belajar, kecerdasan, latar belakang keluarga, budaya, suku, agama, dan lain-lain. Perbedaan karakteristik ini adalah sebuah keniscayaan, yang akan bersinergi menjadi satu harmoni dalam proses pembelajaran di kelas; baik kelas heterogen maupun homogen.

Guru sebagai pemimpin dalam proses pembelajaran, dituntut agar dapat merangkul perbedaan karakteristik siswa tersebut. Hal ini sesuai dengan kompetensi pedagogik yang harus dikuasai oleh guru, yaitu kemampuan untuk mengelola pembelajaran yang salah satunya meliputi pemahaman terhadap siswa dan mengembangkan siswa untuk mengaktualisasikan berbagai potensi yang dimilikinya (Sanjaya, 2007).

Tidak ada siswa yang bodoh. Hanya saja mereka belum menemukan cara belajar yang tepat untuk mengembangkan potensinya. Disinilah peran sentral guru sebagai fasilitator. Guru harus mampu membimbing dan memfasilitasi siswa dalam belajar. Bagaimanapun kondisi awalnya, tujuan pembelajaran harus tercapai.

Dengan demikian, guru harus mahir dalam menciptakan suasana 


\section{$\pi$ (Phi)}

pembelajaran yang dapat merangkul keberagaman siswa, yang membuat semua siswa belajar. Salah satu cara yang memastikan bahwa semua siswa belajar adalah melalui Differentiated Instruction (Cox, 2012). Makalah ini akan membahas tentang apa, mengapa, dan bagaimana menerapkan Differentiated Instruction dalam pembelajaran.

\section{PEMBAHASAN}

Pendekatan Differentiated Instruction (DI): Apa dan Mengapa?

Differentiated Instruction atau

Differentiated Learning atau

Differentiated Teaching pertama kali diperkenalkan oleh Carol Ann Tomlinson. Menurut Tomlinson (2000), Differentiated Instruction (DI) bukanlah strategi, program, atau "sesuatu". DI adalah cara berpikir. Sebuah filosofi bagaimana menanggapi perbedaan siswa dengan mengadaptasi pengajaran untuk memenuhi kebutuhan siswa. Pada buku yang lain, Tomlinson (Butler dan Lowe, 2008) mengemukakan bahwa DI adalah suatu pembelajaran yang disesuaikan dengan kebutuhan siswa dengan tujuan untuk memaksimalkan potensi setiap siswa.

Senada dengan itu, ASCD atau Association of Supervision and Curriculum Development (Kaufelt, 2008) mendefinisikan DI dengan suatu bentuk pembelajaran yang berusaha memaksimalkan pertumbuhan belajar siswa dengan cara mencari informasi sampai ditingkat mana kemampuan belajar siswa, kemudian membantunya untuk lebih berkembang dan lebih maju. Lebih rinci, Access Center (2005) mendefinisikan bahwa DI adalah sebuah proses untuk meningkatkan belajar siswa dengan cara menyesuaikan karakteristik siswa dengan pembelajaran dan penilaian, yang tidak hanya menggunakan satu strategi melainkan menggabungkan beberapa strategi.

Dengan demikian, DI dapat diibaratkan seperti resep dari dokter. Dokter akan memberikan resep kepada pasien sesuai dengan dosis yang diperlukan oleh pasien. Dosis yang sesuai akan dapat menyembuhkan pasien dari penyakit yang dideritanya. Dengan kata lain, DI dirancang agar semua siswa dapat belajar dengan cara yang mereka inginkan. Seperti yang dikemukakan oleh Bao (2010) "If children do not learn the way we teach them, then we must teach them the way they learn".

Mengapa harus dibedakan? Ada tiga perspektif yang dapat menjawab pertanyaan ini (Arends, 2013) yaitu perbedaan dalam perkembangan kognitif dan kemampuan, intelegensi ganda, serta gaya dan preferensi belajar.

Seperti yang telah diketahui, bahwa perkembangan kognitif anak melalui beberapa tahapan, yaitu dimulai dengan keterampilan sensorik dan motorik kasar, berpikir konkret, dan operasi abstrak. Walaupun tahapan yang dilalui oleh setiap anak sama, namun proses perkembangannya dilalui dalam kecepatan yang berbeda-beda. Dan guru bertanggungjawab untuk merencanakan pembelajaran sesuai dengan tahapan perkembangan kognitif siswa. Selain itu, guru juga harus mengetahui zona perkembangan proksimal siswa, yaitu perbedaan antara perkembangan aktual siswa dan apa yang dapat dilakukannya secara mandiri dan tingkat perkembangan potensial siswa dan apa yang dapat dicapainya dengan bantuan dari orang dewasa atau teman sejawat yang lebih mahir.

Guru juga harus menyadari, bahwa setiap anak terlahir dengan kecerdasan ganda (multiple intelligence), yaitu matematis-logis, linguistik, musik, ruang (spasial), 


\section{$\pi$ (Phi)}

kinestetik, interpersonal, intrapersonal, dan naturalis. Sementara itu, profil belajar siswa juga harus mendapat perhatian khusus. Siswa belajar dengan cara yang berbeda-beda, sesuai dengan gaya belajarnya masing-masing. Ada siswa cepat memahami ketika didukung oleh visualisasi, suara atau gerakan atau ketiganya sekaligus dalam waktu yang bersamaan.

Guru harus mengetahui semua perbedaan tersebut. Hal ini dikarenakan agar guru dapat memberikan pengalaman belajar yang sesuai dengan tingkat perkembangan dan kebutuhannya. Menurut Byrnes (Joseph, Thomas, Simonette \& Ramsook, 2013) jika siswa diberikan tugas-tugas dibawah level kemampuannya, maka siswa tidak dapat berkembang. Jika siswa diberikan tugas diatas level kemampuannya maka siswa akan bingung dan frustasi. Oleh sebab itu, penting bagi guru untuk memberikan pengalaman belajar yang berbeda kepada masing-masing siswa sesuai dengan kebutuhannya agar potensi siswa dapat berkembang dengan baik. Tapi tidak berarti bahwa pembelajaran yang dibedakan dilakukan secara individual.

\section{Penerapan Differentiated Instruction \\ Differentiated Instruction (DI)} adalah cara untuk menyesuaikan pembelajaran berdasarkan kebutuhan siswa. Sehingga, untuk menerapkan DI ada tiga langkah yang harus dilakukan, yaitu mengumpulkan informasi tentang siswa, merancang DI, dan menerapkan DI dalam pembelajaran.

\section{Mengumpulkan informasi tentang siswa}

Informasi yang dikumpulkan tentang siswa meliputi readiness (kesiapan belajar siswa), interest (minat), dan learning profile (profil belajar).

a) Readiness atau kesiapan belajar

Kesiapan belajar siswa dalam hal ini dapat diartikan sebagai kemampuan atau pengetahuan awal siswa terhadap materi yang akan dipelajari. Perlu diperhatikan bahwa kesiapan belajar bukanlah tingkat intelektualitas (IQ) siswa. Tujuan membedakan siswa berdasarkan kesiapan belajar adalah untuk memvariasikan tingkat kesulitan pada bahan pembelajaran, sehingga dapat dipastikan bahwa semua siswa diberikan tantangan yang tepat dalam pengalaman belajarnya (Joseph, Thomas, Simonette \& Ramsook, 2013).

\section{b) Interest atau minat}

Memperoleh informasi awal tentang minat siswa berguna agar guru dapat merangkul perhatian, keingintahuan, dan keterlibatan siswa dalam belajar (Tomlinson dan Imbeau, 2010). Ketika guru membedakan siswa berdasarkan minat, maka siswa akan termotivasi untuk menghubungkan apa yang akan dipelajari dengan sesuatu yang sudah mereka ketahui (Joseph, Thomas, Simonette \& Ramsook, 2013). Membedakan siswa berdasarkan minat adalah dengan mengelompokkan siswa berdasarkan minat yang sama seperti musik, olahraga, binatang peliharaan (Joseph, Thomas, Simonette \& Ramsook, 2013).

c) Learning profile atau profil belajar Membedakan siswa berdasarkan profil belajar akan memberikan kesempatan kepada siswa untuk belajar secara natural dan efesien (Joseph, Thomas, Simonette \& Ramsook, 2013). Profil belajar siswa meliputi gaya belajar siswa (audio, visual, dan kinestetik), preferensi belajar (sendiri, berpasangan, atau berkelompok), 


\section{$\pi$ (Phi)}

suasana belajar (tenang atau diiringi dengan musik, pencahayaan). Profil belajar siswa ini dapat diketahui dengan menyebarkan angket sederhana.

\section{Merancang DI}

Pembelajaran DI dirancang dengan membedakan isi, proses, dan produk berdasarkan perbedaan kesiapan belajar, minat, dan profil belajar siswa.

\section{a) Content (isi)}

Tomlinson (2000) menjelaskan bahwa differensiasi isi merujuk pada pengetahuan dan keterampilan yang dipelajari oleh siswa. Dalam merancang pembelajaran yang berdifferensiasi isi ada tiga hal yang harus diperhatikan (Hall, 2010), yaitu: (1) guru harus menggunakan tindakan, konsep, generalisasi, prinsip-prinsip, sikap dan keterampilan; (2) menyelaraskan tugas dengan tujuan pembelajaran; dan (3) isi instruksi harus membahas konsep yang sama pada semua siswa, tetapi tingkat kompleksitas harus disesuaikan sesuai dengan keberagaman siswa.

Heacox (Joseph, Thomas, Simonette \& Ramsook, 2013) mengemukakan bahwa guru dapat mendifferensiasi berdasarkan isi dengan menyediakan kesempatan pada siswa untuk memilih subtopik dalam topik utama yang dipelajari, kemudian setiap siswa mempresentasikannya di kelas sehingga semua siswa dapat memahami keseluruhan topik utama.

\section{b) Process (proses)}

Differensiasi berdasarkan proses yaitu kegiatan siswa dalam rangka memahami isi (Tomlinson, 2000) yang meliputi: penggunaan aktivitas berpikir tingkat tinggi, instruksi kelompok kecil, multiple inteligence, pemusatan pembelajaran, mind-mapping, dan tugas kooperatif (Bao, 2010). Sedangkan Hall (2010) mengemukakan

differensiasi proses meliputi pengelompokkan yang fleksibel dan menggunakan berbagai strategi dalam proses pembelajarannya. Dengan demikian, differensiasi proses adalah suatu kegiatan beragam yang dilakukan selama proses pembelajaran.

Pengelompokkan yang fleksibel diharapkan dapat meningkatkan pemahaman siswa terhadap materi yang baru. Gurudapat melakukan sebuah pengantar dari materi pembelajaran pada seluruh kelas, kemudian diikuti dengan diskusi kelompok kecil atau kerja berpasangan. Setelah itu siswa dilatih untuk menyelesaikan tugas yang diberikan baik dari dalam (bersama teman kelompok) atau oleh guru. Pengelompokan siswa tidak tetap, karena merupakan dasar dari DI. Pengelompokan dan regrouping harus menjadi proses yang dinamis, berubah dengan konten, proyek, dan terusmenerus dievaluasi (Bao, 2010).

Sedangkan menurut Tomlinson (2000) defferensiasi proses adalah membedakan tugas yang diberikan kepada siswa agar dapat memungkinkan siswa untuk berlatih dan memahami isi (content) materi, yang meliputi: (1) menyediakan berbagai alternatif cara dalam mengeksplorasi konsep materi; (2) mengilustrasikan konsep materi agar mudah dipahami; dan (3) memodifikasi kompleksitas pengilustrasian dari berbagai tingkatan kognitif siswa.

\section{c) Product (produk)}

Produk yaitu hasil belajar siswa yang merupakan hasil latihan, penerapan, dan pengembangan apa yang telah dipelajari siswa (Tomlinson, 2000). Diferensiasi berdasarkan produk meliputi: tugas berjenjang, rubrik, penilaian alternatif, pekerjaan rumah yang dimodifikasi, dan proyek independen (Bao, 2010). Ketika membedakan produk, siswa dapat 


\section{$\pi$ (Phi)}

memilih diantara tugas yang bervariasi. Setiap siswa belajar dengan materi yang sama dan proses seperti yang lainnya, namun memiliki titik akhir individu.

Menurut Arends (2013) pada pengajaran yang dibedakan atau Differentiated Instruction, ada beberapa strategi pembelajaran yang dapat digunakan oleh guru, yaitu sebagai berikut.

1) Differensiasi menggunakan
intelegensi ganda

Tabel 1.Strategi Pembelajaran Berbasis Intelegensi Ganda

\begin{tabular}{|c|c|c|}
\hline Intelegensi & Deskripsi & Strategi Pengajaran \\
\hline Matematis-logis & $\begin{array}{l}\text { Kemampuan untuk memahami pola- } \\
\text { pola logis dan numerik untuk } \\
\text { mengelola rantai-rantai pemikiran yang } \\
\text { panjang. }\end{array}$ & $\begin{array}{l}\text { - Pengasah otak } \\
\text { - Pemecahan masalah } \\
\text { - Eksperimen ilmiah } \\
\text { - Permainan angka } \\
\text { - Berpikir kritis }\end{array}$ \\
\hline Linguistik & $\begin{array}{l}\text { Kepekaan terhadap bunyi, ritme dan } \\
\text { arti kata dan terhadap fungsi-fungsi } \\
\text { bahasa yang berbeda. }\end{array}$ & $\begin{array}{l}\text { - Uraian } \\
\text { - Diskusi } \\
\text { - Permainan kata } \\
\text { - Bercerita } \\
\text { - Deklamasi } \\
\text { - Menulis jurnal }\end{array}$ \\
\hline Musik & $\begin{array}{l}\text { Kemampuan untuk menghasilkan dan } \\
\text { mengapresiasi nada, warna suara, } \\
\text { irama,dan bentuk-bentuk ekspresi } \\
\text { musik yang berbeda-beda. }\end{array}$ & $\begin{array}{l}\text { - Pelajaran yang berirama } \\
\text { - Menari rap } \\
\text { - Menggunakan lagu yang } \\
\text { mengandung materi pelajaran }\end{array}$ \\
\hline Spasial & $\begin{array}{l}\text { Kemampuan untuk menangkap dunia } \\
\text { visual-spasial secara akurat dan untuk } \\
\text { menampilkan transformasi pada } \\
\text { persepsi seseorang, baik secara } \\
\text { khayalan maupun nyata }\end{array}$ & $\begin{array}{l}\text { - Presentasi visual } \\
\text { - Kegiatan seni } \\
\text { - Permainan imajinasi } \\
\text { - Pemetaan pikiran } \\
\text { - Metafora } \\
\text { - Visualisasi }\end{array}$ \\
\hline $\begin{array}{l}\text { Kinestetik- } \\
\text { jasmani }\end{array}$ & $\begin{array}{l}\text { Kemampuan untuk menggunakan } \\
\text { kekuatan yang besar dalam gerakan- } \\
\text { gerakan fisik dan untuk menangani } \\
\text { benda-benda secara terampil }\end{array}$ & $\begin{array}{l}\text { - Hands-on learning } \\
\text { - Drama } \\
\text { - Olahraga yang mengandung } \\
\text { materi pelajaran } \\
\text { - Kegiatan taktil (berkaitan } \\
\text { dengan indera perasa) } \\
\text { - Latihan relaksasi }\end{array}$ \\
\hline Interpersonal & $\begin{array}{l}\text { Kecakapan untuk melihat dan } \\
\text { menanggapi seacar tepat suasana hati, } \\
\text { perangai, motivasi, dan keinginan- } \\
\text { keinginan orang lain }\end{array}$ & $\begin{array}{l}\text { - Belajar kelompok } \\
\text { - Mengajari teman sekelas } \\
\text { - Ikut kegiatan masyarakat } \\
\text { - Pertemuan sosial } \\
\text { - Simulasi }\end{array}$ \\
\hline Intrapersonal & $\begin{array}{l}\text { Kecerdikan mengenai keadaan emosi } \\
\text { sendiri dan pengetahuan akan kekuatan } \\
\text { dan kelemahan diri sendiri }\end{array}$ & $\begin{array}{l}\text { - Pengajaran perseorangan } \\
\text { - Belajar mandiri } \\
\text { - Kebebasan memilih bidang }\end{array}$ \\
\hline
\end{tabular}




\begin{tabular}{|c|c|c|}
\hline Intelegensi & Deskripsi & Strategi Pengajaran \\
\hline & & $\begin{array}{l}\text { pelajaran } \\
\text { - Pembentukan sikap } \\
\text { - Penghargaan diri }\end{array}$ \\
\hline Naturalis & $\begin{array}{l}\text { Kemampuan untuk membedakan } \\
\text { benda-benda hidup dan kepekaan } \\
\text { terhadap fitur-fitur alam }\end{array}$ & $\begin{array}{l}\text { - Studi alam } \\
\text { - Kesadaran ekologis } \\
\text { - Kepedulian } \\
\text { binatang/hewan }\end{array}$ \\
\hline
\end{tabular}

2) Differensiasi kurikulum

Agar diferensiasi dapat berjalan, kurikulum yang digunakan harus dimodifikasi. Setiap siswa memiliki kemampuan, minat, dan kesiapan belajar yang berbeda-beda, sehingga konten pembelajaran yang ditemukan dalam buku teks dan dijabarkan dalam kerangka kurikulum harus dimodifikasi agar sesuai dengan kebutuhan siswa. Hal ini berarti menyediakan lebih banyak waktu bagi beberapa orang siswa untuk mengembangkan pemahaman yang penting, sementara memperpendek waktu pembelajaran bagi siswa lain. Guru harus berfokus pada hal-hal yang penting daripada mencakup banyak hal tapi tidak mendalam. Untuk membuat diferensiasi kurikulum, guru harus mampu mengintegrasikan proses pembelajaran yang disesuaikan dengan perbedaan siswa dengan standar yang harus dicapai oleh siswa tersebut.

\section{3) Pembelajaran kooperatif}

Pembelajaran kooperatif adalah suatu proses pembelajaran dimana siswa belajar dan bekerja dalam kelompokkelompok kecil secara kolaboratif yang anggotanya terdiri dari 4-8 orang, dengan struktur pengelompokkannya bersifat heterogen (Slavin dalam Hosnan, 2014). Lebih lanjut, Hosnan (2014) mengemukakan bahwa tujuan dari pembelajaran kooperatif adalah: (1) meningkatkan kinerja siswa dalam tugas-tugas akademik, penerimaan yang luas; (2) penerimaan yang luas terhadap orang yang berbeda menurut ras, budaya, kelas sosial, kemampuan, minat, dan bakat; dan (3) mengajarkan kepada siswa keterampilan bekerja sama dan kolaborasi. Dalam melaksanakan pembelajaran kooperatif, ada enam langkah utama yang harus dilakukan guru (Hosnan, 2014) yaitu menyampaikan tujuan dan motivasi siswa, menyajikan informasi, mengorganisasikan siswa ke dalam kelompok-kelompok belajar, membimbing kelompok belajar, evaluasi dan memberikan penghargaan.

4) Pembelajaran berbasis masalah

Pembelajaran berbasis masalah meletakkan siswa pada peran aktif ketika mereka menyelidiki situasi yang membingungkan dan masalah yang jawabannya tidak jelas. Siswa yang menggunakan pendekatan ini dapat menyelidiki masalah dengan berbagai cara menggunakan pendekatan dan sumber daya mereka sendiri. Pembelajaran berbasis masalah memungkinkan siswa untuk menyumbangkan kekuatan mereka, menggunakan talenta khusus, mengidentifikasi masalah pilihan mereka sendiri, dan merancang proyek yang menangani masalah dengan cara yang otentik dan menantang.

5) Memadatkan kurikulum dan pengajaran

Jika siswa memiliki pemahaman yang kuat mengenai pengetahuian dan keterampilan yang terkait dengan 


\section{$\pi$ (Phi)}

pelajaran tertentu, guru dapat memadatkan kurikulum untuk pelajaran ini. Hal ini berarti mengkaji ulang konten pelajaran dengan cepat dan kemudian mengizinkan beberapa siswa untuk melanjutkan ke gagasan, konsep, dan keterampilan yang lebih kompleks dan tingkat lebih tinggi.

6) Kegiatan yang berjenjang

Kegiatan ini memungkinkan semua siswa untuk berfokus pada pemahaman dan keterampilan yang sama, tetapi dengan abstraksi dan kompleksitas yang berbeda-beda. Ketika guru menggunakan kegiatan berjenjang, penting kiranya bahwa mereka meningkatkan tingkat tantangan bagi siswa yang memiliki pengetahuan dan keterampilan khusus dalam bidang tertentu.

Dogde (Arends, 2013)

mengemukakan tiga tahap dalam mengembangkan tugas berjenjang yaitu: (1) mengembangkan tugas untuk pembelajar tingkat kelas; mengembangkan tugas bagi siswa yang bersusah payah dan menyediakan dukungan untuk memastikan kesuksesan mereka dalam mengerjakan tugas; dan (3) mengembangkan tugas yang menantang untuk pembelajar yang lebih mahir. Tugas ini harus melebarkan tingkat fungsi mereka, tidak hanya menambah pekerjaan.

7) Belajar mandiri dan kontrak pembelajaran

Strategi ini menuntut siswa untuk belajar secara mandiri. Siswa dan guru membuat kesepakatan tentang topik pembelajaran yang akan dikerjakan oleh siswa. Siswa diberikan kebebasan untuk memilih sumber belajar yang diinginkan sesuai dengan topik pembelajaran yang telah disepakati. Strategi ini akan (1) memungkinkan siswa untuk bekerja pada kecepatan yang tepat, didasarkan pada gaya belajar, dan (3) membantu siswa bekerja secara mandiri, dan belajar keterampilan perencanaan. Fokus dari strategi ini adalah kesiapan dan profil belajar.

8) Pengelompokkan fleksibel

Pengelompokkan fleksibel atau flexible groupingmerupakan salah satu praktik pokok dalam kegiatan diferensiasi pembelajaran. Praktik ini meliputi kegiatan yang membuat siswa tetap dalam kelas reguler dan menempatkan mereka pada kelompokkelompok kecil pada sementara waktu. Pengelompokkan siswa dapat berdasarkan kesiapan, gaya belajar, dan profil belajar. Siswa dapat juga dikelompokkan dalam kelompok besar, kelompok kecil, atau berpasangan.

9) Papan pilihan Tic Tac Toe Strategi ini memberikan kesempatan kepada siswa untuk berpartisipasi dalam beberapa tugas, yang dapat melatih keterampilan yang telah dipelajari dan menunjukkan serta memperluas pemahaman konsep mereka. Siswa diminta untuk memilih tiga dari beberapa tugas yang disediakan secara berdekatan atau diagonal. Papan pilihan ini berdasarkan pada kesiapan siswa, minat, dan preferensi belajar.

Adapun langkah-langkah dalam strategi papan pilihan Tic Tac Toe adalah sebagai berikut.

a) Identifikasi hasil dan fokus pembelajaran

b) Gunakan data penilaian dan profil siswa untuk menentukan kesiapan siswa, gaya belajar, dan minat.

c) Desain sembilan tugas/soal yang berbeda.

d) Atur tugas-tugas tersebut di papan pilihan Tic Tac Toe 


\section{$\pi$ (Phi)}

e) Pilihlah satu tugas yang akan dikerjakan oleh semua siswa. Letakkan di bagian tengah papan.

f) Siswa harus menyelesaikan tiga tugas, salah satu tugas yang harus diselesaikan adalah tugas yang terletak pada bagian tengah papan. Tiga tugas yang harus dikerjakan harus memenuhi baris Tic Tac Toe.

\section{Menerapkan DI dalam Pembelajaran}

Beberapa prinsip-prinsip dan karakteristik yang perlu diperhatikan dalam pembelajaran kelas yang heterogen (Tomlinson, 2000) yaitu:

1) Penilaian terus-menerus (on going) dan terkait erat dengan instruksi.

2) Guru adalah pencari dan pengumpul informasi tentang siswa dan bagaimana siswa belajar pada suatu kondisi tertentu. Hasil yang didapatkan guru tentang kesiapan siswa, minat, dan pola belajar siswa dapat membantu guru merencanakan langkah selanjutnya dalam membuat instruksi.

3) Guru bekerja keras untuk memastikan "penghargaan" untuk semua siswa.

Setiap karya siswa harus dihargai sama, bagaimanapun hasil karya itu. sama-sama menarik, dan samasama berfokus pada pemahaman esensial dan keterampilan yang ingin dicapai.

4) Fleksibel adalah ciri khas kelas pengelompokan, dasar pengelompokan siswa tidak monoton. Dapat diubah sesuai kebutuhan, misalnya pada dua pertemuan awal pengelompokan siswa berdasarkan gaya belajar, maka pada pertemuan selanjutnya dapat diubah berdasarkan kesiapan siswa.

5) Guru merencanakan memperpanjang periode instruksi sehingga semua siswa belajar dengan berbagai rekannya selama pembelajaran.

6) Menggunakan soal terbuka

\section{Studi Relevan}

Beberapa studi berkenaan dengan Differentiated Instruction melaporkan bahwa DI dapat meningkatkan kemampuan matematis siswa. Haswati (2015) melaporkan temuannya bahwa kemampuan literasi matematis siswa SMP kelas DI yang dikelompokkan berdasarkan gaya belajar (audio, visual, dan kinestetik) dan menggunakan LKS yang sesuai dengan gaya belajar siswa lebih baik daripada kelas konvensional. Hasil yang serupa juga ditemukan pada disposisi matematis siswa SMP (Defitriani, 2015). Defitriani (2015) menerapkan DI dengan berbagai strategi pembelajaran yang meliputi multiple intelligence, pembelajaran kooperatif tipe quick on the draw, tugas berjenjang, tic-tac-toe, dan pengelompokkan fleksibel sesuai dengan kebutuhan siswa.Pada siswa SMK (Yuliana, 2013), kemampuan pemahaman siswa kelas DI secara signifikan lebih baik daripada siswa kelas konvensional. Selain itu, kecemasan matematika pada siswa yang belajar dengan DI juga dapat direduksi karena proses pembelajaran santai dan nyaman (Yuliana, 2013).

Penelitian yang dilakukan oleh Butler dan Lowe (2008) yang menerapkan DI pada calon guru pendidikan matematika, menunjukkan bahwa siswa yang belajar di kelas DI lebih baik pada pemahaman materi pecahan daripada siswa kelas kontrol. Sedangkan respon siswa terhadap DI, tidak semuanya menunjukkan kepuasan terhadap pembelajaran.

Chamberlin (2008) menerapkan DI pada calon guru matematika. Analisis kualitatif dan kuantitatif 


\section{$\pi$ (Phi)}

menunjukkan bahwa calon guru merespon positif terhadap DI. Mereka mengemukakan bahwa DI dapat mendukung berbedaan kebutuhan mereka dan mereka berencana untuk menerapkan DI pada pembelajaran mereka yang akan datang.

Joseph, Thomas, Simonette \& Ramsook (2013) juga melakukan penelitian dengan menerapkan DI pada calon guru. Penelitian ini menemukan bahwa calon guru merespon dengan baik DI, dengan $99 \%$ responden mau untuk mencoba DI pada sesi praktikum berikutnya selama mereka masih berada di universitas, dan $88 \%$ terindikasi mempunyai keinginan yang kuat untuk menerapakan DI pada kelas mereka setelah tamat.

\section{SIMPULAN}

Differentiated Instruction adalah suatu cara yang dilakukan untuk merangkul semua perbedaan kebutuhan siswa dalam belajar. Sehingga, DI dapat membuat semua siswa belajar dengan cara yang sesuai dengan keinginan dan kebutuhan mereka masing-masing. DI dirancang sesuai dengan perbedaan kesiapan belajar (readiness), minat (interest), dan profil belajar (learning profile) siswa. Berdasarkan perbedaan ini, guru dapat merancang pembelajaran dengan membedakan content (isi), process (proses), dan product (product). Diharapkan pada semua guru agar dapat memperhatikan perbedaan karakteristik siswa yang meliputi kemampuan kognitif, motivasi, minat dan bakat, serta gaya belajar siswa dalam proses pembelajaran, sehingga semua siswa dapat mengembangkan potensi yang dimilikinya karena diberikan pengalaman belajar yang tepat dan sesuai. Salah satu cara yang dapat dilakukan untuk mengatasi perbedaan siswa adalah menerapkan Differentiated Instruction dalam proses pembelajaran.
Jurnal Pendidikan Matematika Volume 2 Nomor 2 Tahun 2018

\section{DAFTAR PUSTAKA}

Access Center. 2005. Differentiated Instruction For Math. [Online]. Tersedia:

http://165.139.150.129/interventio n/Differentiated\%20Instruction\%

20for\%20Math.pdf. [1 Oktober 2014]

Arends, R. 2013. Belajar Untuk Mengajar. Learning To Teach. PT Salemba: Humanika Jakarta

Bao, J. 2010. Teaching and Learning Strategies for Differentiated Instruction in the Language Classroom. [Online]. Tersedia: http://steinhardt.nyu.edu/teachlear n /dclt/Summer_Institute_2010. [20 Oktober 2014]

Butler, M. and Van Lowe, K. 2008. Using Differentiated Instruction in Teacher Education.International Journal for Mathematics Teaching and Learning. [Online]. Tersedia: http://www.cimt.plymouth.ac.uk/j ournal/default.htm [1 Desember 2014]

Chamberlin, M. 2008. The Potential of Prospective Teachers Experiencing Differentiated Instruction in a Mathematics Course. International Electronic Journal of Mathematics Education. 6 (3) hal 134-156

Cox, J.T. 2012. Differentiated Mathematics Instruction So Everyone Learn. White Paper. STEM

Defitriani, E. 2015.Penerapan Pendekatan Differentiated Instruction untuk Meningkatkan Kemampuan Koneksi dan Disposisi Matematis Siswa SMP. Bandung: Tesis SPs UPI. Tidak Diterbitkan

ESA. 2006. Strategies that Differentiate Instruction. Esa region $6 \& 7$ 
Haswati, D. 2015. Penerapan Pendekatan Differentiated Instruction (DI) Berdasarkan Gaya Belajar untuk Meningkatkan Kemampuan Literasi Matematis Siswa SMP. Bandung: Tesis SPs UPI. Tidak Diterbitkan

Hosnan. 2014. Pendidikan Saintifik Dan Kontekstual Dalam Pembelajaran Abad 21. Kunci Sukses Implementasi Kurikulum 2013. Bogor: Ghalia Indonesia

Joseph, S., Thomas, M., Simonette, G., \& Ramsook, L. 2013. The Impact of Differentiated Instruction in a Teacher Education Setting: Success and Challenges. International Journal of Higher Education 2(3) hal 28-40.

Sanjaya, W. 2007.Strategi Pembelajaran Berorientasi Standar Proses Pendidikan. Jakarta: Kencana

Tomlinson. 2000. What is Differentiated Instruction? Alexandria: Association for Supervision and Curriculum Development.

Yuliana, N. 2013. Pengaruh Pendekatan Differentiated Instruction (DI) terhadap Kecemasan Matematika (Math Anxiety), Peningkatan Kemampuan Pemahaman dan Penalaran Matematis Siswa SMK. Bandung: Tesis SPs UPI. Tidak Diterbitkan 